\title{
Analisis Faktor-Faktor yang Berpengaruh terhadap Ibu Hamil Trimester III Melakukan Antenatal Care K4
}

\author{
Lia Fitria ${ }^{1}$ \\ Prodi DIII Kebidanan, Universitas Ibrahimy Sukorejo Situbondo, Indonesia ${ }^{I}$ \\ e-mail:leeafitria@gmail.com
}

\begin{abstract}
Antenatal Care (ANC) is one of the supporting factors to reduce maternal mortality. The maternal mortality rate in Indonesia reaches 228 / 100,000 and the target to be achieved in the Millennium Development Goals (MDGs), which is equal to 110 per 100,000 live births. This study aims to analyze the factors associated with the low coverage of Antenatal Care K4. The research design in this study is a survey. The population in this study were all Trimester III pregnant women in Sumberejo Village by using purposive sampling. The data that has been obtained is analyzed using multiple logistic regression tests. Data that has been obtained from the assessment was analyzed using multiple logistic regression statistical tests. In the knowledge factor, the value of $p=0.541$, while the distance factor for pregnant women to health workers is $p=0.019$. Based on the results of the above analysis, it can be concluded that the knowledge factor Ho is accepted, meaning that there is no influence of knowledge factors on third trimester pregnant women doing Antenatal Care K4, while the distance factor for pregnant women Ho is rejected, meaning that there are influences of perception factors and distance of pregnant women to health workers against Antenatal Care K4. It is hoped that the results of this study can be useful especially for health workers to improve Antenatal Care K4 as a means of early detection of a complication of pregnancy or childbirth.
\end{abstract}

Keywords: antenatal care K4, knowledge factor, pregnant women

\section{Pendahuluan}

Angka Kematian Ibu (AKI) dan Angka Kematian Bayi (AKB) merupakan indikator penting dari derajat kesehatan masyarakat dan keberhasilan pelayanan kesehatan serta masalah kesehatan di seluruh negara. Angka Kematian Ibu (AKI) di dunia pada tahun 2010 diperkirakan World Health Organization (WHO) mencapai 287 per 100.000 jiwa dan penyumbang terbesar berasal dari negara berkembang yang mencapai 99\% (284 per 100.000 jiwa), sehingga penurunan AKI merupakan target yang ingin dicapai pada Millenium Development Goal's (MDG's) tahun 2015. (WHO, 2012).

Jumlah kematian ibu di Provinsi Jawa Timur berdasarkan laporan pada tahun 2010 tercatat sebanyak 598 kasus kematian, yang dapat dirinci 152 kematian pada ibu hamil, 163 waktu bersalin dan 283 pada saat nifas. Menurut Kementrian Kesehatan RI penyebab langsung kematian ibu antara lain adalah perdarahan, eklampsia, partus lama, komplikasi aborsi dan infeksi (Dinas Kesehatan Propinsi Jawa Timur, 2010).

Upaya menurunkan angka kematian ibu (AKI) terdapat dalam intervensi strategis dalam upaya safe motherhood yang dinyatakan sebagai empat pilar safe motherhood, dimana salah satunya yaitu pelayanan antenatal. Yang mana pelayanan antenatal ini merupakan pelayanan kesehatan kepada ibu hamil selama masa kehamilan yang dilakukan oleh tenaga kesehatan. Akses pelayanan kebidanan antenatal bertujuan untuk mencegah adanya komplikasi obstetrik dan bisa memastikan bahwa komplikasi dideteksi sedini mungkin serta bisa ditangani secara memadai oleh petugas kesehatan (Prawirohardjo, 2008).

Berdasarkan sumber data dari Ditjen Binkesmas Kemenkes RI mengenai cakupan kunjungan ulang ke empat (K4) pada tahun 2008 dan 2009 di Indonesia. Dapat diketahui cakupan K4 pada tahun 2008 adalah sebesar 86\% sedangkan pada tahun 2009 terdapat penurunan sebesar 1\% $(85 \%)$.

Sementara di Wilayah Propinsi Jawa Timur cakupan K4 yang paling besar adalah pada tahun 2010 yaitu sebesar $88,07 \%$ dengan peningkatan $2,17 \%$ dari cakupan K4 pada tahun 2009 (85,9\%). Sementara untuk tahun 2011 bulan September cakupan K4 di jawa timur 
sebesar 46,04\%. Berdasarkan data yang diperoleh dari dinas kesehatan propinsi jawa timur terdapat 21 kabupaten yang cakupan K4nya dibawah target $90 \%$ dengan kisaran antara 67,85\% - 89,02\%.

Diantara 21 Kabupaten tersebut termasuk didalamnya adalah kabupaten situbondo. Berdasarkan kajian tersebut, maka perlu dilakukan penelitian tentang "faktor - faktor yang berpengaruh terhadap ibu hamil trimester III melakukan Antenatal Care k4" diharapkan nantinya dapat digunakan sebagai bahan kajian untuk petugas kesehatan dalam meningkatkan cakupan K4 sehingga bisa berupaya untuk menurunkan AKI dan AKB.

\section{Metode}

Penelitian ini merupakan observasional analitik dengan pendekatan cross sectional.

\subsection{Metode Pengumpulan Data}

Populasinya yaitu semua ibu hamil Trimester III dengan jumlah populasi sebanyak $172 \mathrm{ibu}$ hamil. Sampel pada penelitian ini adalah sebagian ibu hamil Trimester III yang di ambil sebanyak 25\% dari populasi. Teknik sampling ini mengadop pendapat dari Arikunto, 2010, sehingga diperoleh 43 responden. Dengan pengambilan sampel secara purposive sampling.

Instrumen yang digunakan dalam pengkajian ini adalah kuesioner dan buku KIA.

\subsection{Metode Analisis Data}

Penelitian ini menggunakan program SPSS sebagai alat mengolah data dengan nilai $\alpha 0,05$. Apabila nilai sig $>0,05$ maka $\mathrm{H}_{0}$ diterima sedangkan $\mathrm{H}_{1}$ ditolak sedangkan jika nilai sig $<0,05$ maka $\mathrm{H} 0$ ditolak sedangkan $\mathrm{H} 1$ diterima.

Adapun teknik yang digunakan untuk melihat ada dan tidaknya pengaruh faktor predisposisi (pengetahuan), faktor pendukung (jarak tempuh kepetugas kesehatan) terhadap kunjungan kehamilan (K4) dianalisis dengan menggunakan uji statistik yaitu regresi logistik berganda.

\section{Hasil dan Pembahasan}

Hasil penelitian disajikan dalam tabel. Tabel 1 menyajikan distribusi tingkat pengetahuan ibu hamil trimester III.

Tabel 1. Distribusi Frekuensi Tingkat Pengetahuan Ibu Hamil Trimester III

\begin{tabular}{llll}
\hline No & $\begin{array}{l}\text { Tingkat } \\
\text { Pengetahuan }\end{array}$ & Frekuensi & $\begin{array}{c}\text { Persentase } \\
\mathbf{( \% )}\end{array}$ \\
\hline 1 & Baik & 11 & 25,58 \\
2 & Cukup & 21 & 48,84 \\
3 & Kurang & 11 & 25,58 \\
\hline Total & 43 & 100 \\
\hline
\end{tabular}

Berdasarkan Tabel 1. dapat diketahui bahwasanya terdapat 21 responden $(48,84 \%)$ yang dikatakan pengetahuannya mengenai K4 cukup sedangkan yang dikatakan pengetahuannya baik dan kurang mengenai $\mathrm{K} 4$ terdapat 11 responden $(25,58 \%)$. Tabel 2 menyajikan jarak tempuh subjek ke petugas kesehatan.

Tabel 2. Distribusi Frekuensi Faktor Jarak Tempuh Ibu Hamil Trimester III Kepetugas Kesehatan

\begin{tabular}{llll}
\hline No & $\begin{array}{l}\text { Jarak } \\
\text { Tempuh } \\
\text { Kepetugas } \\
\text { Kesehatan }\end{array}$ & Frekuensi & $\begin{array}{l}\text { Persen } \\
\text { tase (\%) }\end{array}$ \\
\hline 1 & Dekat & 8 & 26,32 \\
2 & Sedang & 27 & 68,42 \\
3 & Jauh & 8 & 5,26 \\
\hline \multicolumn{2}{l}{ Total } & 43 & 100 \\
\hline
\end{tabular}

Tabel 2 menunjukkan bahwa sebagian besar jarak tempuh ibu hamil kepetugas kesehatan yaitu sekitar 0,5-2 km yang dikategorikan sedang yaitu sebanyak 27 responden (68,42\%). Kunjungan ulang keempat (K4) subjek disajikan dalam tabel 3.

Tabel 3. Distribusi Frekuensi Kunjungan Ulang Keempat (K4)

\begin{tabular}{llll}
\hline No & $\begin{array}{l}\text { Kunjungan } \\
\text { Kehamilan }\end{array}$ & Frekuensi & $\begin{array}{c}\text { Persentase } \\
(\mathbf{\%})\end{array}$ \\
\hline 1 & Rutin & 21 & 42,11 \\
2 & Tidak rutin & 22 & 57,89 \\
\hline Total & & 43 & 100 \\
\hline
\end{tabular}


Tabel 3. dapat diketahui bahwa sebanyak 21 responden $(42,11 \%)$ ibu hamil melakukan kunjungan antenatal dengan rutin sedangkan 22 responden $(57,89 \%) \mathrm{ibu}$ hamil melakukan kunjungan yang tidak rutin bahkan tidak kunjungan sama sekali. Hasil tabulasi silang pengetahuan ibu dengan kunjungan ulang keempat dapat dilihat pada tabel 4 .

Tabel 4. Tabulasi Silang Pengaruh Pengetahuan Ibu Hamil terhadap Kunjungan Ulang Keempat (K4)

\begin{tabular}{|c|c|c|c|c|c|c|}
\hline \multirow{3}{*}{$\begin{array}{l}\text { Pengeta } \\
\text { huan }\end{array}$} & \multicolumn{4}{|c|}{ K4 } & \multirow{2}{*}{\multicolumn{2}{|c|}{ Total }} \\
\hline & \multicolumn{2}{|c|}{ Rutin } & \multicolumn{2}{|c|}{$\begin{array}{l}\text { Tidak } \\
\text { Rutin } \\
\end{array}$} & & \\
\hline & $\sum$ & $\%$ & $\sum$ & $\%$ & $\sum$ & $\%$ \\
\hline Baik & 9 & 82 & 2 & 18 & 11 & 100 \\
\hline Cukup & 9 & 43 & 12 & 57 & 21 & 100 \\
\hline Kurang & 3 & 27 & 8 & 73 & 11 & 100 \\
\hline
\end{tabular}

Tabel 4. menunjukkan bahwa pengetahuan responden yang dikategorikan baik melakukan kunjungan kehamilan dengan rutin sebanyak $82 \%$, sedangkan pengetahuan responden yang diketegorikan cukup, tidak rutin melakukan kunjungan kehamilan yaitu sebanyak 12 dari 21 responden (43\%) dan responden yang dikategorikan pengetahuannya kurang yang tidak rutin melakukan kunjungan kehamilan yaitu sebanyak 73\% (8 dari 11 responden).

Berdasarkan hasil uji regresi logistik dengan SPSS didapatkan nilai sig 0,016 yang artinya $\mathrm{p}<\alpha(0,05)$ sehingga $\mathrm{H}_{0}$ di tolak yang artinya ada pengaruh faktor pengetahuan ibu hamil terhadap kunjungan ulang keempat (K4). Sedangkan tabulasi silang jarak tempuh subjek ke petugas kesehatan dengan frekuensi kunjungan ulang keempat disajikan dalam tabel 5 .

Tabel 5. Distribusi Pengaruh Jarak Tempuh Ibu Hamil Kepetugas Kesehatan terhadap Kunjungan Ulang Keempat (K4)

\begin{tabular}{|c|c|c|c|c|c|c|}
\hline \multirow{3}{*}{$\begin{array}{l}\text { Jarak } \\
\text { Tempuh } \\
\text { Kepetu } \\
\text { gas Kese } \\
\text { hatan }\end{array}$} & \multicolumn{4}{|c|}{ K4 } & \multirow{2}{*}{\multicolumn{2}{|c|}{ Total }} \\
\hline & \multicolumn{2}{|c|}{ Rutin } & \multicolumn{2}{|c|}{$\begin{array}{l}\text { Tidak } \\
\text { Rutin }\end{array}$} & & \\
\hline & $\sum$ & $\%$ & $\sum$ & $\%$ & $\sum$ & $\%$ \\
\hline Dekat & 7 & 87,5 & 1 & 12,5 & 8 & 100 \\
\hline
\end{tabular}

\begin{tabular}{lllllll}
\hline Sedang & 11 & 40,7 & 16 & 59,2 & 27 & 100 \\
Jauh & 3 & 37,5 & 5 & 62,5 & 8 & 100 \\
\hline
\end{tabular}

Berdasarkan tabel 5 menunjukkan bahwa jarak tempuh responden yang dekat $(<0,5 \mathrm{~km})$ dengan petugas kesehatan dan rutin melakukan kunjungan kehamilan yaitu sebanyak $87,5 \%$, sedangkan yang dikategorikan sedang $(0,5-2 \mathrm{~km})$ dan tidak rutin melakukan kunjungan kehamilan terdapat 16 dari 27 responden $(59,2 \%)$ dan terdapat 5 dari 8 responden yang jarak tempuhnya jauh $(>2 \mathrm{~km})$ dengan petugas kesehatan dan tidak rutin melakukan kunjungan kehamilan.

Berdasarkan hasil uji regresi logistik dengan SPSS didapatkan nilai sig 0,002 yang artinya $\mathrm{p}<\alpha(0,05)$ sehingga $\mathrm{H}_{0}$ di tolak yang artinya ada pengaruh faktor jarak tempuh ibu hamil kepetugas kesehatan terhadap kunjungan kehamilan (K4).

Untuk mengetahui pengaruh tiap variabel independen yang dikaji terhadap variabel dependen maka dilakukan uji regresi logistik dengan SPSS pada tiap variabel yang dikaji yaitu faktor pengetahuan dan faktor jarak tempuh ibu hamil kepetugas kesehatan, sehingga didapatkan kedua faktor tersebut berpengaruh terhadap kunjungan ulang keempat (K4).

Pelayanan kehamilan adalah pelayanan yang diberikan kepada ibu hamil selama masa kehamilannya sesuai dengan standart pelayanan antenatal seperti yang ditetapkan (Wijono, 2008). Untuk memperoleh pelayanan yang maksimal dipengaruhi oleh faktor-faktor diantaranya faktor pengetahuan dan jarak tempuh. Dari kedua faktor tersebut dalam pengkajian ini faktor yang paling dominan yang mempengaruhi kunjungan kehamilan (K4) adalah faktor persepsi, dimana suatu kemampuan untuk memahami suatu objek yang dalam hal ini adalah kunjungan kehamilan. Ibu yang yang mempunyai persepsi positif terhadap kunjungan kehamilan yang didukung dengan keadaan georafis yang memadai, hal tersebut merupakan faktor pendorong dan pendukung responden untuk memperoleh 
ISSN : 2354-5852

e-ISSN : 2579-5783

pelayanan kesehatan, sedangkan apabila mempunyai pengetahuan yang baik namun tidak mempunyai persepsi yang positif mengenai kunjungan kehamilan dan didukung oleh keadaan geografis yang tidak mendukung, hal tersebut akan mempengaruhi keterhambatan responden untuk memperoleh pelayanan kesehatan khususnya pelayanan antenatal.

\section{Simpulan dan Saran}

\subsection{Simpulan}

Ada pengaruh faktor pengetahuan ibu hamil trimester III dan faktor jarak tempuh ke petugas kesehatan terhadap kunjungan ulang $(\mathrm{K} 4)(\mathrm{p}=0,002)$.

\subsection{Saran}

Bagi peneliti selanjutnya agar dapat lebih menggali faktor-faktor lainnya dari yang berpengaruh terhadap kunjungan kehamilan (K4)

\section{Daftar Pustaka}

Dinas Kesehatan Propinsi Jawa Timur. (2010). Profil Kesehatan Jawa Timur 2010. Dinas Kesehatan Jawa Timur : Surabaya.

Emilda S, Mahdalena E. (2015). Analisis Penyebab Ibu Melakukan Kunjungan
Antenatal Care K4 Di Puskesmas Pembantu Karta Dewa Kecamatan Talang Ubi Kabupaten Pali.

Kamo B, Msen Y, Rantetampang AL, Mallongi A. (2018). The factors affecting with four visited at public health center province Mimika Papuan Province. International journal of science and healthcare research. Volume 3 Issue 2.

Meiriza W, Aladin, Edison. (2017). The correlation of maternal factors and the quality of antenatal care services with low birth weight babies in health facilities level I. Journal of Midwifery. Volume 2 Nomer 1.

Nofitasari. (2012). Pengaruh Pengetahuan Ibu Hamil Tentang Antenatal Care Terhadap Frekuensi Kunjungan Antenatal Care Pada Ibu Hamil Trimester III. Karya Tulis Ilmiah : Akbid Ibrahimy

Prawirohardjo, Sarwono. (2008). Ilmu Kebidanan Sarwono Prawirohardjo. Jakarta.

Sari PI, Efendy V. (2013). Analisis Faktor Yang Berpengaruh Terhadap Kunjungan Antenatal Care. Jurnal Keperawatan dan Kebidanan. Page 93-113. 